\title{
Iron bound to pectin is utilised by rats
}

\author{
Tomihiro Miyada ${ }^{1}$, Akira Nakajima ${ }^{1}$ and Kiyoshi Ebihara ${ }^{2 *}$ \\ ${ }^{1}$ Department of Food and Nutrition, Matsuyama Shinonome Junior College, Kuwabara 3-2-1, Matsuyama 790-0853, Japan \\ ${ }^{2}$ Department of Biological Resources, Faculty of Agriculture, School of Agriculture, Ehime University, Tarumi 3-5-7, \\ Matsuyama 790-8566, Japan
}

(Received 16 August 2010 - Revised 9 December 2010 - Accepted 14 December 2010 - First published online 27 April 2011)

\section{Abstract}

In the present in vitro study, the effects of $\mathrm{pH}$ and ionic strength on the release of iron from pectin and the ability of pectin to reduce ferric iron to ferrous iron were examined. The bioavailability of Fe bound to pectin was evaluated in rats. The amount of Fe released from pectin was at a maximum at $\mathrm{pH} 2 \cdot 0$ and decreased as the $\mathrm{pH}$ value increased. At $\mathrm{pH} 2 \cdot 0$, the amount of Fe released from pectin increased as the ion length increased; at $\mathrm{pH} 5 \cdot 0$, ion length had no effect on pectin release. Pectin effectively reduced Fe from the ferric form to the ferrous form. In rats fed a pectin diet, where Fe bound to pectin was the only Fe source, the final $\mathrm{Hb}$ concentration using diets containing $4 \cdot 4-5 \cdot 7$, 7.2 or $11.5 \mathrm{mg} \mathrm{Fe} / \mathrm{kg}$ diet was equal to the concentration in rats fed diets containing $4.5,7.6$ or $13.5 \mathrm{mg}$ ferrous iron/kg diet, respectively. $\mathrm{Hb}$ regeneration efficiencies in rats fed pectin diets were significantly different from rats fed a diet containing $13.5 \mathrm{mg}$ ferrous iron/ $\mathrm{kg}$ diet. In rats fed a diet with or without pectin, where ferric iron was the only Fe source, pectin increased the final Hb concentration. These results suggest that Fe bound to pectin is utilised by rats.

Key words: Iron bound to pectin: pH value: Ionic strength: Iron absorption

Fe deficiency is the most common human nutritional deficiency in the world. It is caused not only by low intake but more often by poor bioavailability from the diet, due to Fe interaction with other dietary components ${ }^{(1)}$. Dietary fibres have been shown to impair the absorption of minerals in the small intestine because of their binding and/or sequestering effect ${ }^{(2,3)}$.

Pectin is primarily a polymer of $\alpha$ - $(1 \rightarrow 4)$-glycosidic-linked D-galacturonic acid residues that are usually esterified to various degrees with methanol $^{(4)}$. Dietary fibres with a high content of carboxyl groups, such as pectin, have increased cation-binding ability, because the carboxyl group is deprotonated when $\mathrm{pH}$ is close to neutrality and can interact electrostatically with mineral cations. At the $\mathrm{pH}$ of the small intestine, about $6 \cdot 5-7 \cdot 0$, carboxyl groups are deprotonated. In solution, the carboxyl groups of the unesterified units of pectin can bind cations such as $\mathrm{Ca}, \mathrm{Mg}$ and $\mathrm{Fe}^{(5-7)}$, supporting the assumption that pectin in the diet would reduce mineral bioavailability. However, if the binding of mineral cations by pectin depends on the carboxyl groups, this binding appears to be reversible and would be affected by $\mathrm{pH}$, ionic strength and temperature. Very few studies have reported on the bioavailability of Fe bound to pectin.

In the present study, we have investigated the availability of Fe bound to pectin.

\section{Materials and methods}

\section{Pectin}

Commercial citrus pectin (Classic AM201) was purchased from Herbstreith \& Fox GmbH (Neuenburg, Germany). The degree of esterification of pectin and the Fe content in pectin are $72 \%$ and $7 \cdot 2 \mu \mathrm{g} / \mathrm{g}$, respectively. The Fe content in pectin was measured by flame atomic absorption spectrophotometry (AA 6400F; Shimadzu, Kyoto, Japan) after wet ashing in $\mathrm{HNO}_{3}-\mathrm{HClO}_{4}(3: 1)$. To determine Fe levels, the standard addition method was used.

\section{In vitro study}

Determination of iron released from pectin by ultrafiltration. The influence of $\mathrm{pH}$ and ion length on the release of $\mathrm{Fe}$ bound to pectin was examined by ultrafiltration.

Briefly, $10 \mathrm{ml}$ of pectin solution $(1 \mathrm{~g} / 100 \mathrm{ml})$ were introduced into the chamber of a batch-type stirred ultrafiltration cell (Model 8010; Amicon, Beverly, MA, USA) fitted with a disc membrane (YC01; Amicon) with a molecular weight cut-off of 500 . The pectin solution was filtered under pressure (about $3.5 \mathrm{~kg} / \mathrm{m}^{3}$ ) of $\mathrm{N}_{2}$ gas until about $20 \%$ of the original volume remained in the cell. The filtrate was collected. The chamber was covered with a polyethylene tube (IGM, outer

Abbreviations: FeD, Fe-deficient diet; FeII-3, Fe at $3 \mathrm{mg} / \mathrm{kg}$ diet; FeII- 6 , Fe at $6 \mathrm{mg} / \mathrm{kg}$ diet; FeII-12, Fe at $12 \mathrm{mg} / \mathrm{kg}$ diet.

*Corresponding author: K. Ebihara, fax +81 89946 9847, email ebihara@agr.ehime-u.ac.jp 
diameter $\times$ inner diameter, $4 \mathrm{~mm} \times 2 \mathrm{~mm}$; HAGITEC Company Limited, Yotsukaido, Chiba, Japan), and the pectin solution in the chamber was maintained at $37^{\circ} \mathrm{C}$ by circulating hot water $\left(37^{\circ} \mathrm{C}\right)$ in the tube.

Before starting the in vitro study, we confirmed that galacturonic acid was not detected in the solution filtered by ultrafiltration. Total Fe content in the filtrate was measured by flame atomic absorption spectrophotometry (AA 6400F; Shimadzu) after wet ashing in $\mathrm{HNO}_{3}-\mathrm{HClO}_{4}$ (3:1). Ferrous iron (FeII) content in the filtrate was determined by the bathophenanthroline method. Ferrous iron + ferric iron (FeII + FeIII) content in the filtrate was determined by the bathophenanthroline method after reducing with hydroxylamine hydrochloride solution $(4 \%, \mathrm{w} / \mathrm{v})$. FeIII content was determined using the difference between FeII and FeII + FeIII measurements. Non-ionic Fe was determined using the difference between FeII + FeIII and total Fe.

Effect of $\mathrm{pH}$ on the release of iron bound to pectin. Briefly, $1 \mathrm{~g}$ of pectin was dissolved in $150 \mathrm{~mm}-\mathrm{NaCl}$ solution to give $10 \mathrm{ml}$ and adjusted to $\mathrm{pH} 2 \cdot 0,3 \cdot 0,5 \cdot 0,7 \cdot 0$ and $9 \cdot 0$ with $0 \cdot 1 \mathrm{M}-\mathrm{HCl}$ or $0 \cdot 1 \mathrm{M}-\mathrm{NaCl}$. The pectin solution was ultrafiltrated, and $8 \mathrm{ml}$ of the filtrate were collected.

Effect of ionic strength on the release of iron bound to pectin. In brief, $1 \mathrm{~g}$ of pectin was dissolved in distilled water to give $10 \mathrm{ml}$ and adjusted to $\mathrm{pH} 2.0$ or 5.0 . The pectin solution was ultrafiltrated, and $8 \mathrm{ml}$ of the filtrate were collected.

Effect of pectin as a reducing agent. Briefly, $0.5 \mathrm{~g}$ of pectin were dissolved in $275 \mathrm{~mm}-\mathrm{NaCl}$ solution to give $40 \mathrm{ml}$ and adjusted to $\mathrm{pH} 2 \cdot 0$ with $0 \cdot 1 \mathrm{M}-\mathrm{HCl}$. The pectin solution was increased to $50 \mathrm{ml}$ using distilled deionised water. The final concentration of $\mathrm{NaCl}$ was $150 \mathrm{~mm}$. Then, $10 \mathrm{ml}$ of pectin solution were ultrafiltrated, and $8 \mathrm{ml}$ were collected. After filtrating, $8 \mathrm{ml}$ of $150 \mathrm{~mm}-\mathrm{NaCl}$ solution containing ferric chloride (Fe of $200 \mathrm{mg} / \mathrm{l}$ ) were added to the residue and the solution was ultrafiltrated. Then, $8 \mathrm{ml}$ of the filtrate were collected. In addition, $0.5 \mathrm{ml}$ of ferric iron solution only (Fe of $200 \mathrm{mg} / \mathrm{l}$ ) was dissolved in $275 \mathrm{~mm}-\mathrm{NaCl}$ solution to give $40 \mathrm{ml}$ and adjusted to $\mathrm{pH} 2 \cdot 0$ with $0 \cdot 1 \mathrm{M}-\mathrm{HCl}$. The ferric iron solution was increased to $50 \mathrm{ml}$ using distilled deionised water. Ferric iron solution $(10 \mathrm{ml})$ was ultrafiltrated, and $8 \mathrm{ml}$ of the filtrate were collected.

\section{In vivo study (animal experiment)}

The present study was approved by the Laboratory Animal Care Committee of Ehime University. Rats were maintained in accordance with the Guidelines for the Care and Use of Laboratory Animals of Ehime University. The Fe content in the experimental diets was determined by flame atomic absorption spectrophotometry (AA 6400F; Shimadzu) after wet ashing in $\mathrm{HNO}_{3}-\mathrm{HClO}_{4}(3: 1)$.

\section{Experiment 1}

Animals and diets. Wistar male rats weighing about $80 \mathrm{~g}$ (Japan SLC, Hamamatsu, Japan) were housed individually in screen-bottomed, stainless-steel cages in a room maintained at $23 \pm 1^{\circ} \mathrm{C}$ with a $12 \mathrm{~h}$ light $-12 \mathrm{~h}$ dark cycle (light on, 07.00-19.00 hours). The rats were acclimatised by feeding a commercial solid diet (MF; Oriental Yeast, Osaka, Japan) for $3 \mathrm{~d}$. After acclimatisation, rats were randomly divided into five groups ( $n$ 6) and were allowed free access to distilled deionised water and one of the following diets for 3 weeks: Fe-deficient diet (FeD); diet containing ferrous iron at 3, 6 or $12 \mathrm{mg} / \mathrm{kg}$ diet (FeII-3, FeII-6 or FeII-12 diets); diet containing pectin at $50 \mathrm{~g} / \mathrm{kg}$ diet (Table 1$)^{(8)}$. For each rat, body weight and food intake were recorded daily in the morning before the food was replaced. Ferrous sulphate $\left(\mathrm{FeSO}_{4} \cdot 7 \mathrm{H}_{2} \mathrm{O}\right)$ was used as the source of ferrous iron. The amount of $\mathrm{Fe} / \mathrm{kg}$ diet of the FeD, FeII-3, FeII-6, FeII-12 and the pectin diet was $1 \cdot 7,4 \cdot 5,7 \cdot 6,13 \cdot 4$ and $5 \cdot 1 \mathrm{mg}$, respectively.

\section{Experiment 2}

Animals and diets. Wistar male rats weighing about $80 \mathrm{~g}$ (Tokushima Jikken-Dobutsu Kenkyusho, Tokushima, Japan) were housed individually in screen-bottomed, stainless-steel cages in a room maintained at $23 \pm 1{ }^{\circ} \mathrm{C}$ with a $12 \mathrm{~h}$ light$12 \mathrm{~h}$ dark cycle (light on, 07.00-19.00 hours). The rats were

Table 1. Composition of the experimental diets

\begin{tabular}{|c|c|c|c|c|c|c|c|c|}
\hline & \multicolumn{5}{|c|}{ Expt 1} & \multicolumn{3}{|c|}{ Expt 2} \\
\hline & $\mathrm{FeD}$ & Fell-3 & Fell-6 & Fell-12 & Pectin & $\mathrm{FeD}$ & Felll & Felll + pectin \\
\hline \multicolumn{9}{|l|}{$\mathrm{g} / \mathrm{kg}$ diet } \\
\hline Vitamin-free casein & 200 & 200 & 200 & 200 & & 200 & 200 & \\
\hline Maize oil & 50 & 50 & 50 & 50 & & 50 & 50 & \\
\hline Vitamin mixture ${ }^{\star} \dagger$ & 10 & 10 & 10 & 10 & $950 \mathrm{~g}$ of $\mathrm{FeD}$ diet & 10 & 10 & $990 \mathrm{~g}$ of FeD diet \\
\hline Fe-free mineral mixture* & 40 & 40 & 40 & 40 & & 40 & 40 & \\
\hline Sucrose & 700 & 700 & 700 & 700 & & 700 & 700 & \\
\hline Pectin & & & & & 50 & & & 10 \\
\hline \multicolumn{9}{|l|}{$\mathrm{mg} / \mathrm{kg}$ diet } \\
\hline $\mathrm{FeSO}_{4} \cdot \mathrm{H}_{2} \mathrm{O}$ & - & 14.9 & 29.9 & $59 \cdot 7$ & - & - & - & - \\
\hline $\mathrm{Fe}_{2}\left(\mathrm{SO}_{4}\right)_{3} \cdot \mathrm{H}_{2} \mathrm{O}$ & - & - & - & - & - & - & $12 \cdot 0$ & $11 \cdot 3$ \\
\hline Iron content & $1 \cdot 7$ & 4.5 & $7 \cdot 6$ & $13 \cdot 4$ & $5 \cdot 1$ & $1 \cdot 7$ & $13 \cdot 3$ & 13.5 \\
\hline
\end{tabular}

FeD, Fe-deficient diet; Fell-3, Fe at $3 \mathrm{mg} / \mathrm{kg}$ diet; Fell-6, Fe at $6 \mathrm{mg} / \mathrm{kg}$ diet; Fell-12, Fe at $12 \mathrm{mg} / \mathrm{kg}$ diet.

${ }^{*}$ Based on AIN-76 ${ }^{(8)}$.

†The vitamin mixture used in the present study contained $20 \mathrm{~g}$ choline chloride. 

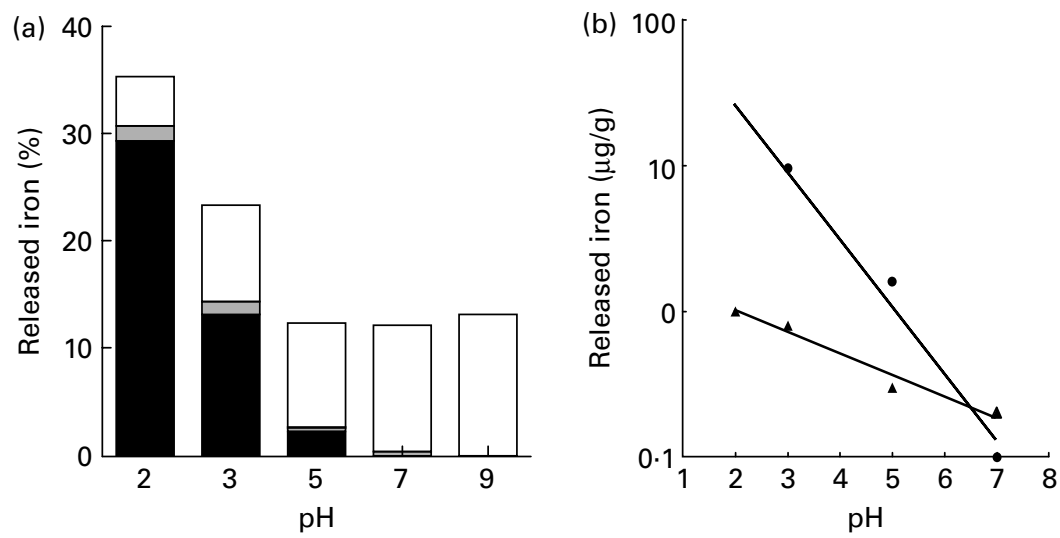

Fig. 1. Effects of $\mathrm{pH}$ on the release of iron bound to pectin: (a) percentage of the released ferrous $(\square)$, ferric $(\square)$ and non-ionic ( $\square$ ) iron from pectin, with solutions at indicated $\mathrm{pH}$ values; (b) relationship between released ferrous iron $\left(\mathrm{Fe}^{2+} ; \bullet\right)$ from pectin and pH $(y=-0.462 x+2.34 ; r-0.991 ; P<0.0079)$ and between released ferric iron $\left(\mathrm{Fe}^{3+} ; \mathbf{\Lambda}\right)$ from pectin and $\mathrm{pH}(y=-0.149 x+0.302 ; r-0.984 ; P<0.0157)$. Values are means of five obervations.

acclimatised by feeding a commercial solid diet (MF; Oriental Yeast) for $3 \mathrm{~d}$. After acclimatisation, rats were randomly divided into three groups ( $n$ 6) and were allowed free access to distilled deionised water and one of the following diets for $21 \mathrm{~d}$ : FeD; FeIII; FeIII + pectin diet (Table 1). FeSO $4.7 \mathrm{H}_{2} \mathrm{O}$ and ferric sulphate $\left(\mathrm{Fe}_{2}\left(\mathrm{SO}_{4}\right)_{3} \cdot n \mathrm{H}_{2} \mathrm{O}\right)$ were used as the sources of ferrous iron and ferric iron, respectively. For each rat, body weight and food intake were recorded daily in the morning before the food was replaced. The amount of Fe/kg diet of the FeD, FeIII and FeIII + pectin diets was $1.7,13.3$ and $13.5 \mathrm{mg}$, respectively.

Chemical analysis. Hb concentration was measured by the cyanmethaemoglobin method using a colorimetric haemoglobin assay kit (Hemoglobin-Test; Wako Pure Chemical Industries Limited, Osaka, Japan). Blood was obtained from the tail tip. To calculate total $\mathrm{Hb}$ content in the blood, the mass of blood was assumed to be $67 \mathrm{~g} / \mathrm{kg}$ body mass, and $\mathrm{Hb}$ was assumed to contain $3.35 \mathrm{mg} \mathrm{Fe} / \mathrm{g}^{(9)}$. Hb regeneration efficiency was calculated according to the method of Mahoney \& Hendricks ${ }^{(10)}$

Statistical analysis. All values in the in vivo studies (animal experiments) are given as means with their standard errors ( $n$ 6), and a $P$ value of less than 0.05 was considered significant using the Tukey-Kramer honestly significant difference test using JMP ${ }^{\circledR} 6$ (SAS Institute Japan, Tokyo, Japan).

\section{Results}

\section{In vitro study}

Effect of $\mathrm{pH}$ on the release of iron bound to pectin. The release of $\mathrm{Fe}$ from pectin was at a maximum at $\mathrm{pH} 2.0$; however, the amount of released Fe was about one-third of the total $\mathrm{Fe}$ contained in pectin. The release of Fe from pectin was linearly decreased as the $\mathrm{pH}$ value increased $(r-0.991$, $P<0.008$ for ferrous iron and $r-0.984, P<0.016$ for ferric iron; Fig. 1). Most of the Fe released from pectin at $\mathrm{pH} 2 \cdot 0$ was ferrous iron. Most of the Fe released from pectin at $\mathrm{pH}$ $9 \cdot 0$ was non-ionic Fe.

Effect of ionic strength on the release of iron bound to pectin. At $\mathrm{pH} 2 \cdot 0$, most of the Fe released from pectin was ferrous iron. The amount of Fe released from pectin at $\mathrm{pH}$ 2.0 increased about two- and fourfold in 150 and $500 \mathrm{~mm}$ $\mathrm{NaCl}$ solutions, respectively, when compared with the solution without $\mathrm{NaCl}$ (Fig. 2). When the concentration of $\mathrm{NaCl}$ solution was increased from 500 to $1000 \mathrm{~mm}$, the amount of
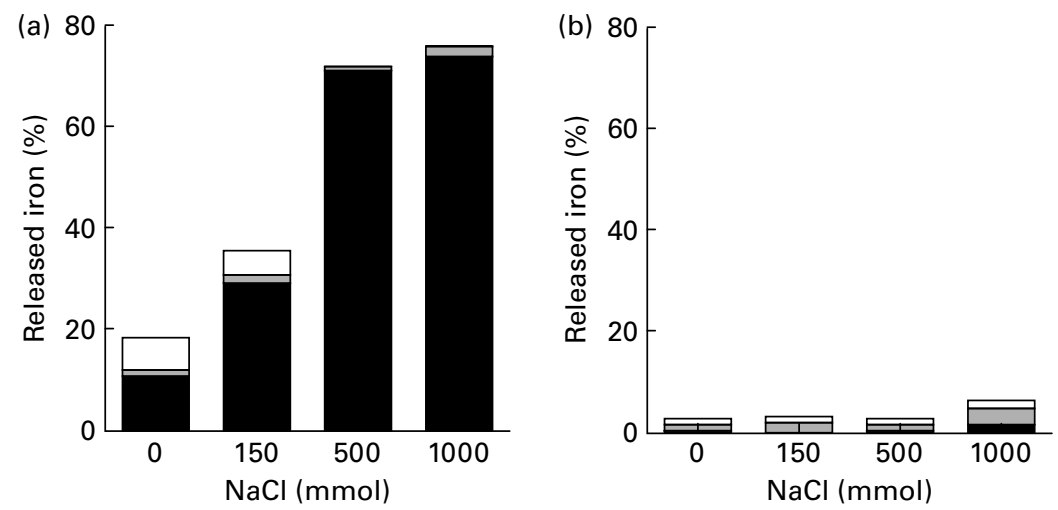

Fig. 2. Effects of ionic strength and pH on the release of iron bound to pectin: percentage of the released ferrous ( $\square$ ), ferric ( $\square$ ) and non-ionic ( $\square$ ) iron from pectin, with solutions at indicated ionic strengths, (a) at $\mathrm{pH} 2.0$ and (b) at $\mathrm{pH} 5.0$. Values are means of five observations. 


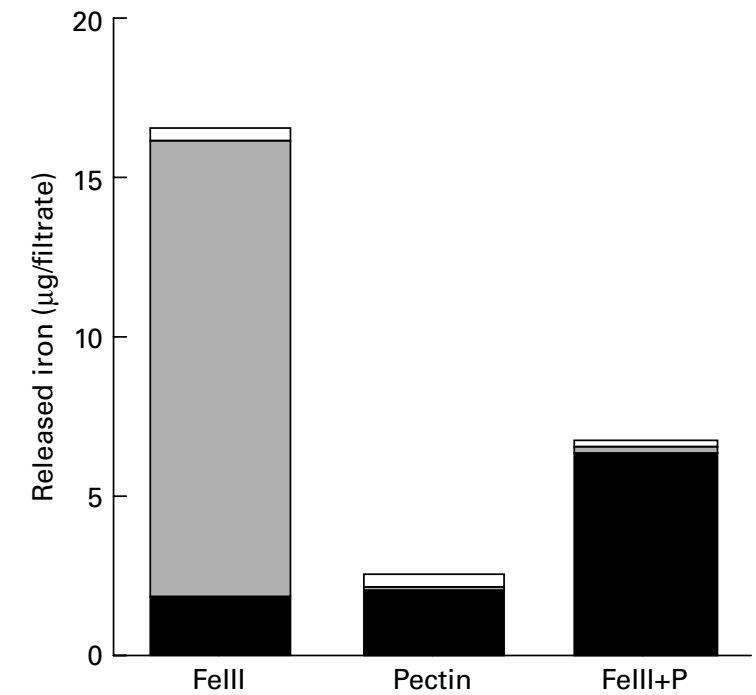

Fig. 3. Reducing effect of pectin to ferric iron: amount of the released ferrous $(\square)$, ferric ( $\square$ ) and non-ionic ( $\square$ ) iron in $150 \mathrm{~mm}-\mathrm{NaCl}$ solution at $\mathrm{pH} 2.0$ with or without pectin. Values are means of five observations.

Fe isolated from pectin did not increase. At $\mathrm{pH} 5 \cdot 0$, the release of Fe from pectin was hardly detectable.

Effect of pectin as a reducing agent. Most of the Fe isolated from the solution without pectin was ferric iron (Fig. 3). However, most of the Fe isolated from the solution containing pectin was ferrous iron.

\section{In vivo study (animal experiment)}

Experiment 1. Body-weight gain in rats fed the FeII-6 and FeII-12 diets was significantly higher compared with rats fed the FeD diet. Body-weight gain in rats fed the FeII- 3 and pectin diets was not significantly different from rats fed the FeD diet (Table 2). Hb concentration in rats fed the FeII-6, FeII-12 and pectin diets was significantly higher compared with rats fed the FeD diet. $\mathrm{Hb}$ concentration in rats fed the FeII-3 diets was not significantly different from rats fed the $\mathrm{FeD}$ diet. $\mathrm{Hb}$ gain and $\mathrm{Hb}$ regeneration efficiencies in rats fed the FeII-3, FeII-6, FeII-12 and pectin diets were significantly higher compared with rats fed the FeD diet. Hb gain and $\mathrm{Hb}$ regeneration efficiency increased as the $\mathrm{Fe}$ intake increased $(r 0.928, P<0.0001$ and $r 0.556, P<0.003)$.

Experiment 2. Body-weight gain in rats fed the FeIII and FeIII + pectin diets was significantly higher compared with rats fed the FeD diet (Table 3). Fe intake was not significantly different between rats fed the FeIII and FeIII + pectin diets; however, $\mathrm{Hb}$ concentration, $\mathrm{Hb}$ gain and $\mathrm{Hb}$ regeneration efficiency in rats fed the FeIII + pectin diet were significantly higher compared with rats fed the FeIII diet.

\section{Discussion}

Pectin contains methylated carboxyl groups. When pectin is dispersed in water, some of the carboxyl groups ionise. Pectin is a polycarboxylic acid with a $\mathrm{p} K_{\mathrm{a}}$ value of about $3 \cdot 5^{(11)}$. The $\mathrm{p} K_{\mathrm{a}}$ value is known to depend on the temperature of the solution. Therefore, in the present in vitro study, the temperature of the pectin solution was kept at $37^{\circ} \mathrm{C}$. At $\mathrm{pH}$ values higher than $3 \cdot 5$, pectin is a negatively charged polysaccharide in its ionised form, which can interact with positively charged Fe. The dissociation of pectin is reversible, depending on $\mathrm{pH}$ conditions. The amount of Fe released from $1 \%$ pectin solution $(\mathrm{w} / \mathrm{v})$ at $\mathrm{pH} 2.0$ was about three times higher than the amount of Fe released at $\mathrm{pH} 5 \cdot 0,7 \cdot 0$ and 9.0. About $90 \%$ of $\mathrm{Fe}$ released from pectin at $\mathrm{pH} 2 \cdot 0$ was ionic Fe. Most of the Fe released from $1 \%$ pectin solution $(\mathrm{w} / \mathrm{v})$ at $\mathrm{pH}$ values higher than 5 was non-ionic Fe. Our results suggest that $\mathrm{Fe}$ and pectin would form an ionic-bound or electric-bound complex with free carboxyl groups in the pectin molecules. Most of the Fe released from $1 \%$ pectin solution $(\mathrm{w} / \mathrm{v})$ at $\mathrm{pH} 2.0$ was ferrous iron, suggesting that most of the Fe bound to pectin is ferrous iron; ferric iron bound to pectin might be reduced to ferrous iron by pectin.

Fe absorption occurs predominantly in the duodenum and upper jejunum ${ }^{(12)}$. Gastric acid lowers the $\mathrm{pH}$ in the proximal duodenum, which enhances the solubility and uptake of Fe. Gastric acid is an important luminal factor in the absorption of non-haem Fe. Depending on the acidity of the stomach, Fe bound to pectin might be partially released before passing into the small intestine. However, ingestion of food causes a transitory $\mathrm{pH}$ rise ${ }^{(13)}$. The mean $\mathrm{pH}$ of the digesta in the upper small intestine in rats fed a commercial pellet was

Table 2. Effect of iron source on body-weight gain, final $\mathrm{Hb}$ concentration, $\mathrm{Hb}$ gain and $\mathrm{Hb}$ regeneration efficiency in rats fed the experimental diet for $21 \mathrm{~d}$ (Mean values with their standard errors)

\begin{tabular}{|c|c|c|c|c|c|c|c|c|c|c|}
\hline & \multicolumn{10}{|c|}{ Diet } \\
\hline & \multicolumn{2}{|c|}{$\mathrm{FeD}$} & \multicolumn{2}{|c|}{ Fell-3 } & \multicolumn{2}{|c|}{ Fell-6 } & \multicolumn{2}{|c|}{ Fell-12 } & \multicolumn{2}{|c|}{ Pectin } \\
\hline & Mean & SE & Mean & SE & Mean & SE & Mean & SE & Mean & SE \\
\hline Body-weight gain (g/21 d) & $124^{\mathrm{a}}$ & 4 & $148^{a, b}$ & 4 & $151^{\mathrm{b}}$ & 7 & $153^{b}$ & 6 & $139^{a, b}$ & 4 \\
\hline Food intake $(\mathrm{g} / 21 \mathrm{~d})$ & $353^{\mathrm{a}}$ & 18 & $534^{\mathrm{b}}$ & 20 & $465^{\mathrm{b}}$ & 14 & $376^{a}$ & 18 & $322^{a}$ & 6 \\
\hline $\mathrm{Fe}$ intake $(\mathrm{mg} / 21 \mathrm{~d})$ & $0.59^{\mathrm{a}}$ & 0.02 & $2 \cdot 40^{\mathrm{d}, \mathrm{e}}$ & 0.01 & $3 \cdot 50^{b, c}$ & 0.10 & $5 \cdot 04^{g}$ & 0.24 & $1 \cdot 63^{\mathrm{e}, \mathrm{f}}$ & 0.03 \\
\hline Final $\mathrm{Hb}$ concentration $(\mathrm{g} / \mathrm{l})$ & $54^{\mathrm{a}}$ & $2 \cdot 0$ & $63^{\mathrm{a}, \mathrm{b}}$ & 1.0 & $76^{\mathrm{c}}$ & 3.0 & $96^{d}$ & 3.0 & $72^{\mathrm{b}, \mathrm{c}}$ & 1.0 \\
\hline $\mathrm{Hb}$ gain $(\mathrm{g} / 21 \mathrm{~d})$ & $0.00^{a}$ & 0.02 & $0.26^{\mathrm{b}}$ & 0.01 & $0.49^{c}$ & 0.01 & $0.79^{d}$ & 0.05 & $0.29^{b}$ & 0.02 \\
\hline $\mathrm{Hb}$ regeneration efficiency (\%) & $-0.3^{a}$ & 7.9 & $37 \cdot 0^{\mathrm{b}}$ & $2 \cdot 2$ & $46 \cdot 7^{b}$ & 1.3 & $53 \cdot 2^{\mathrm{b}}$ & 3.4 & $60 \cdot 1^{\mathrm{b}}$ & $4 \cdot 8$ \\
\hline
\end{tabular}

FeD, Fe-deficient diet; Fell-3, Fe at $3 \mathrm{mg} / \mathrm{kg}$ diet; Fell-6, Fe at $6 \mathrm{mg} / \mathrm{kg}$ diet; Fell-12, Fe at $12 \mathrm{mg} / \mathrm{kg}$ diet. a,b,c,d,e,f,g Mean values within a row with unlike superscript letters were significantly different $(P<0.05)$. 
Table 3. Effect of pectin on body-weight gain, final $\mathrm{Hb}$ concentration, $\mathrm{Hb}$ gain and $\mathrm{Hb}$ regeneration efficiency in rats fed a diet containing ferric sulphate as the iron source for $21 \mathrm{~d}$

(Mean values with their standard errors)

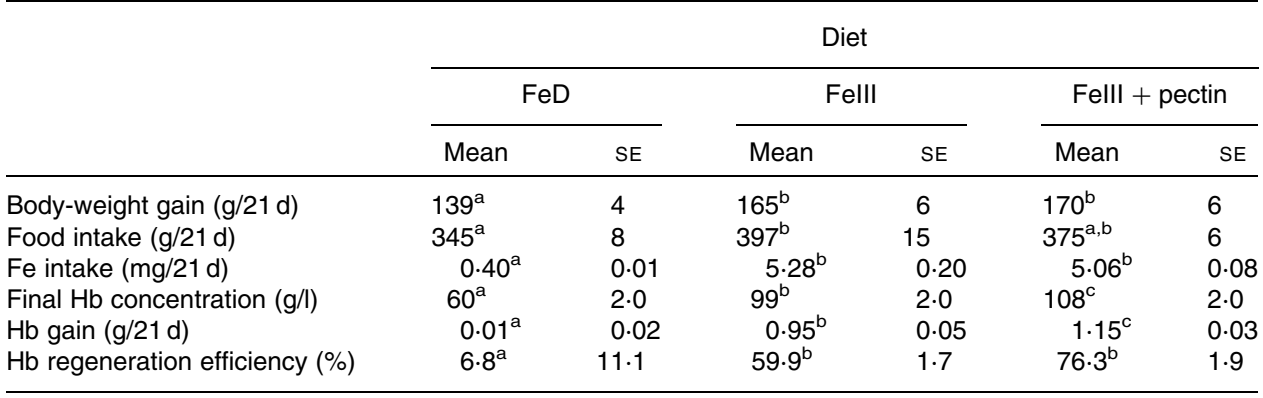

FeD, Fe-deficient diet

a,b,c Mean values within a row with unlike superscript letters were significantly different $(P<0.05)$

about $6 \cdot 0^{(14)}$. At or above $\mathrm{pH} 4$, Fe was not released from dietary fibres such as maize bran and soya hull ${ }^{(15)}$

In addition to the effect of $\mathrm{pH}$, ionic strength is also a critical parameter in the release of Fe from pectin. The $\mathrm{p} K_{\mathrm{a}}$ value rises as ionic strength increases.

The amount of Fe released from pectin at $\mathrm{pH} 2 \cdot 0$ increased as the ionic strength of the pectin solution increased; however, at $\mathrm{pH} 5 \cdot 0, \mathrm{Fe}$ release was not increased, suggesting that the release of Fe from pectin is affected by $\mathrm{p} K_{\mathrm{a}}$ and $\mathrm{pH}$. Solutions with $\mathrm{KCl}$ concentrations as high as $150 \mathrm{~mm}$ released less than $10 \%$ of Fe from maize bran and soya hull ${ }^{(15)}$.

The fate of pectin in the large intestine is also extremely important with regard to the bioavailability of $\mathrm{Fe}$ bound to pectin. Pectin is almost completely fermented in the caecum of rats, resulting in the release of Fe from pectin. In ileally fistulated rats, ferrous and ferric iron infused in the caecum was similarly utilised ${ }^{(16,17)}$. Fe absorption from the large intestine is less efficient compared with the duodenum, but it is significant, especially, during Fe deficiency ${ }^{(18)}$. Studies of gastrectomised rats have shown that dietary fructo-oligosaccharides prevented anaemia, but this effect was diminished by caecectomy $^{(19)}$, suggesting that $\mathrm{Fe}$ absorption takes place to some extent in the colon. Acidic fermentation in the large intestine stimulates absorption of $\mathrm{Ca}$ and $\mathrm{Mg}$ in the large intestine of the rat ${ }^{(20)}$. Therefore, increased Fe absorption in the presence of pectin could depend on the decrease in $\mathrm{pH}$ due to fermentation of pectin in the large intestine.

Ferrous iron is absorbed much more efficiently than ferric iron. Under physiological conditions, it is thought that inorganic forms of Fe need to be reduced to the ferrous form to be effective. When ferric iron was added to the filtrate of pectin solution, most of the $\mathrm{Fe}$ in the filtrate was ferrous iron, suggesting that pectin has reducing potential. In Expt 2 of the present in vivo study, the final $\mathrm{Hb}$ concentration, $\mathrm{Hb}$ gain and $\mathrm{Hb}$ regeneration efficiency in rats fed the FeIII + pectin diet were significantly higher compared with rats fed the FeIII diet. Therefore, the higher bioavailability of ferric iron in rats fed the FeIII + pectin diet compared with those fed the FeIII diet would partially depend on an increased $\mathrm{Fe}$ absorption in the upper small intestine by the reduction of ferric iron to ferrous iron by pectin.
In our other study, the amount of Fe released from pectin was not proportional to the amount of Fe bound to pectin, suggesting that the amount of $\mathrm{Fe}$ released from pectin depends on the type and source of pectin. In comparison with rats fed the FeD diets containing various pectin concentrations, the $\mathrm{Hb}$ gain increased as $\mathrm{Fe}$ intake from pectin increased $(r 0.962, P<0.0001)$, but it did not increase as the Fe bound to pectin increased ( $\mathrm{T}$ Miyada and $\mathrm{K}$ Ebihara, unpublished results). The degree of esterification, molecular weight and/or mode of distribution of free carboxylic groups along the polymer chain strongly affect the strength of binding of minerals to pectin ${ }^{(6,21,22)}$

In conclusion, the release of Fe from pectin was increased at lower $\mathrm{pH}$ and higher ionic strength. The Fe bound to pectin is utilised by rats

\section{Acknowledgements}

The present study was supported, in part, by the Iijima Memorial Foundation. The authors declare that there are no conflicts of interests to disclose. T. M., A. N. and K. E. conducted the research; T. M. and A. N. analysed the data; T. M. and K. E. managed the study and drafted the manuscript; K. E. had the primary responsibility for the final content. All authors read and approved the final manuscript.

\section{References}

1. Baynes RD \& Bothwell TH (1990) Iron deficiency. Annu Rev Nutr 10, 133-148.

2. Bosscher D, Van Caillie-Bertrand M \& Deelstra H (2001) Effect of thickening agents, based on soluble dietary fiber, on availability of calcium, iron, and zinc from infant formulas. Nutrition 17, 614-618.

3. Fuchs GJ, Farris RP, DeWier M, et al. (1993) Iron status and intake of older infants fed formula vs. milk with cereal. Am J Clin Nutr 58, 343-348.

4. Van Soest PJ (1984) Some physical characteristics of dietary fibers and their influence on the microbial ecology of the human colon. Proc Nutr Soc 43, 25-33.

5. BeMiller JN (1986) An introduction to pectins: structure and properties. In Chemistry and Function of Pectins, pp. 23-37 [ML Fishman and JJ Jen, editors]. Washington, DC: American Chemical Society. 
6. Kohn R, Furda I \& Kopec Z (1968) Distribution of free carboxylic groups in the pectin molecule after treatment with pectin esterase. Collect Czech Chem Commun 33, 264-269.

7. Debon SJJ \& Tester RF (2001) In vitro binding of calcium, iron and zinc by non-starch polysaccharides. Food Chem 73, 401-410.

8. American Institute of Nutrition (1977) Report of the American Institute of Nutrition ad hoc Committee on Standards for Nutritional Studies. J Nutr 107, 1340-1348.

9. Miller J (1982) Assessment of dietary iron availability by rat Hb repletion assay. Nutr Rep Int 26, 993-1005.

10. Mahoney AW \& Hendricks DG (1982) Efficiency of hemoglobin re-generation as a method of assessing iron bioavailability in food products. In Nutritional Bioavailability of Iron, 2nd ed., ACS Symposium Series 203, pp. 1-10 [C Kies, editor]. Washington, DC: American Chemical Society.

11. Sila DN, Van Buggenhout S, Duvetter T, et al. (2009) Pectins in processed fruits and vegetables: part II - structure-function relationships. Comp Rev Food Sci Food Safety 8, 86-104

12. Muir A \& Hopfer U (1985) Regional specificity of iron uptake by small intestinal brush-border membranes from normal and iron deficient mice. Am J Physiol 248, G376-G379.

13. Ovesen L, Bendtsen F, Tage-Jenesen U, et al. (1986) Intraluminal $\mathrm{pH}$ in the stomach, duodenum, and proximal jejunum in normal subjects and patients with exocrine pancreatic insufficiency. Gastroenterology 90, 958-962.
14. Shiga A, Sakai T \& Horii N (1987) Correlations among pH and $\mathrm{Mg}, \mathrm{Ca}, \mathrm{Na}, \mathrm{K}, \mathrm{Cl}^{-}$and $\mathrm{HCO}_{3}^{-}$contents of digesta in the gastro-intestinal tract in rats. Jpn J Vet Sci 49, 973-979.

15. Laszlo JA (1989) Effect of gastrointestinal conditions on the mineral-binding properties of dietary fibers. Adv Exp Med Biol 249, 133-145.

16. Ebihara K, Okano J \& Miyada T (1994) Comparison of ferrous and ferric iron bioavailability following rat cecal infusion. Nutr Res 14, 221-228.

17. Ebihara K \& Okano J (1995) Comparison of bioavailability and hemogobin replation of ferric and ferrous iron infused into the cecum in anemic rats. Nutr Res 15, 889-897.

18. Yeung CK, Glahn RP, Welch RM, et al. (2005) Prebiotics and iron bioavailability - is there a connection? J Food Sci $\mathbf{7 0}$, R88-R92.

19. Sakai K, Ohta A, Shiga K, et al. (2000) The cecum and dietary short-chain fructooligosaccharides are involved in preventing postgastrectomy anemia in rats. J Nutr 130, 1608-1612.

20. Demigné C \& Rémésy C (1985) Stimulation of absorption of volatile fatty acids and minerals in the cecum of rats adapted to a very high fiber diet. J Nutr 115, 53-60.

21. Kim M \& Atallah MT (1993) Intestinal solubility and absorption of ferrous iron in growing rats are affected by different dietary pectins. J Nutr 123, 117-124.

22. Kim M, Atallah MT, Amarsiwardena C, et al. (1996) Pectin with low molecular weight and high degree of esterification increases absorption of ${ }^{59} \mathrm{Fe}$ in growing rats. J Nutr $\mathbf{1 2 6}$, $1883-1890$. 